\author{
Л.Т. Бойко*, О.І. Бабаченко**, Г.А. Кононенко**, І.В. Попов* \\ *Дніпровський національний університет імені Олеся Гончара \\ ** Інститут чорної металургї імені 3.І. Некрасова НАН Украӥни
}

\title{
АЛГОРИТМ РОЗВ'ЯЗУВАННЯ РЕАЛЬНОЇ ОДНОВИМІРНОЇ ЗАДАЧІ ТЕПЛОПРОВІДНОСТІ ДЛЯ СУЦІЛЬНОГО НЕОБМЕЖЕНОГО СТАЛЕВОГО ЦИЛІНДРА
}

Об'єктом дослідження с температурне поле суцільного, нескінченого циліндра, який у розігрітому стані переміщено в охолоджуюче середовище. Математична модель цісї задачі складається 3 одновимірного квазілінійного диференціального рівняння теплопровідності, початкових і граничних умов. Безрозмірний варіант цієї математичної задачі розв'язано сітковим методом. Програмна реалізація алгоритму перевірена на реальному прикладі. Результати очікувані.

Ключові слова: суцільний сталевий циліндр, квазілінійне рівняння теплопровідності, метод сіток, візуалізація результатів.

\author{
L.T. Boiko*, O.I. Babachenko**, G.A. Kononenko**, I.V. Popov* \\ *Oles Honchar Dnipro National University \\ **Iron and Steel Institute of Z.I. Nekrasov of NAS Ukraine
}

\section{ALGORITHM FOR SOLVING A REAL ONE-DIMENSIONAL HEAT CONDUCTION PROBLEM FOR A SOLID INFINITE STEEL CYLINDER}

An infinite continuous steel cylinder of radius $R$ is considered. The temperature field $T$ is assumed in the cylinder region, which is assumed to be symmetric about the $\mathrm{Oz}$ axis. At the initial time, the lateral surface of the cylinder is instantly cooled to a certain temperature, it is necessary to determine the temperature distribution $T$ inside the cylinder at any time. Typical in thermophysical studies is a situation where the thermophysical properties depend on not only spatial coordinates and time but also on the temperature, in this case, we obtain a quasi-linear heat conduction equation.

There is a problem with rounding errors when you approach the task on a computer. To reduce the effect of rounding errors on the accuracy of the approximate solution, the transformation to dimensionless variables was made. The transition to dimensionless variables begins with the choice of values to be scaled. Scale factors were selected and the transformation to dimensionless variables for temperature, spatial coordinate, time coordinate, and thermophysical coefficients was made.

Thermal-physical coefficients of steel depend on temperature, but this dependence is established only experimentally. To obtain the values of the physical properties of the steel at any temperature, the method of least squares was used to obtain the density, heat conductivity, and specific heat dependences on the temperature in analytical form, these dependencies were used to find dimensionless coefficients of the physical properties of the steel.

This math problem is solved by the net-point method using the explicit template. The computer program is developed in $\mathrm{C}++$ language for the numerical implementation of net-

Бойко Л.Т., Бабаченко О.І., Кононенко Г.А., Попов І.В., 2020 
point method algorithms in the software development environment MS Visual Studio 2017. The program is verified in a test case, the results are expected.

Keywords: solid steel cylinder, quasilinear equation of thermal conductivity, mesh method, results visualization.

\author{
Л.Т. Бойко*, А.И. Бабаченко**, А.А. Кононенко**, И.В. Попов* \\ *Днипровский национальный университет имени Олеся Гончара \\ ** Институт чёрной металлургии имени 3.И. Некрасова НАН Украины
}

\title{
АЛГОРИТМ РЕШЕНИЯ РЕАЛЬНОЙ ОДНОМЕРНОЙ ЗАДАЧИ ТЕПЛОПРОВОДНОСТИ ДЛЯ СПЛОШНОГО БЕСКОНЕЧНОГО СТАЛЬНОГО ЦИЛИНДРА
}

\begin{abstract}
Объектом исследования является температурное поле сплошного бесконечного цилиндра, который в разогретом состоянии перемещен в охлаждающую среду. Математическая модель этой задачи состоит из одномерного квазилинейного дифференциального уравнения теплопроводности, начальных и граничных условий. Безразмерный вариант этой математической задачи решен методом сеток. Программная реализация алгоритма решения проверена на реальном примере. Результаты ожидаемые.

Ключевые слова: сплошной стальной цилиндр, квазилинейное уравнение теплопроводности, метод сеток, визуализация результатов.
\end{abstract}

Вступ. При проведені наукових досліджень широко використовують можливості сучасної обчислювальної техніки та методи комп'ютерного моделювання реальних процесів. Такий підхід дозволяє встановити більш тісну взаємодію експериментальних та теоретичних досліджень.

В умовах сучасного промислового виробництва велике значення має скорочення матеріальних та часових ресурсів при розробці нових технологій та освоєнні нового сортаменту продукції і нових марок сталей. Для термічної обробки металовиробів ці питання можна вирішити за допомогою сучасних методів моделювання та розрахунків, які при мінімальних витратах часу та матеріальних засобів дозволяють досліджувати різні технологічні процеси, проводити їх розробку та оптимізацію для різних матеріалів.

Ряд видів масового металопрокату має форму, наближену до циліндра великої довжини (арматура, круг, дріт, труби), більшість із них підлягають термічній обробці.

Постановка задачі. Розглядаємо суцільний сталевий круговий циліндр радіуса $R$ та достатньо великої довжини. Матеріал циліндра вважаємо однорідним та ізотропним. В початковий момент часу розігрітий циліндр перенесемо в середовище охолодження. Досліджуємо температурне поле циліндра під час його охолодження. Вважаємо, що температурне поле не змінюється вздовж осі циліндра та є симетричним відносно цієї осі, тобто не залежить від полярного кута. 
Математична модель такої фізичної задачі складається із рівняння теплопровідності, записаного в циліндричній системі координат $(r, \theta, z)[1]$

$$
c(T) \cdot \rho(T) \cdot \frac{\partial T}{\partial t}=\frac{1}{r} \cdot \frac{\partial}{\partial r}\left(r \cdot k(T) \cdot \frac{\partial T}{\partial r}\right)+f(r, t), \quad(t>0,0<r<R) .
$$

Тут $T(r, t)$ - шукана температура циліндра, яка є функцією лише двох змінних: просторової координати $r \in[0, R]$ та часу $t \in\left[0, t_{\max }\right]$, момент часу $t_{\max }$ фіксується користувачем-дослідником.

До теплофізичних характеристик матеріалу циліндра відносяться: $c(T)-$ питома теплоємність, $\rho(T)$ - густина матеріалу, $k(T)$ - коефіцієнт теплопровідності. Теплофізичні характеристики матеріалу залежать від шуканої температури, але ці залежності для кожного конкретного матеріалу відомі лише у вигляді експериментально побудованих таблиць. При цьому, для одного і того ж матеріалу таблиці цих трьох теплофізичних характеристик відрізняються фіксованими значеннями температури.

Функція $f(r, t)$ в рівнянні (1) описує щільність теплових джерел в циліндpi і вважається відомою аналітично.

До диференціального рівняння (1) беремо такі додаткові умови:

$$
\begin{array}{cc}
T(r, 0)=\varphi(r), & r \in[0, R] . \\
T(R, t)=T_{\text {noв }}(t), & t \in\left[0, t_{\max }\right] . \\
\left.\frac{\partial T(r, t)}{\partial r}\right|_{r=0}=0 ; & T(0, t) \neq \infty .
\end{array}
$$

В початковій умові (2) відома аналітично функція $\varphi(r)$ описує температуру циліндра в початковий момент часу $t=0$.

В крайовій умові (3) функція $T_{\text {пов }}(t)$ описує зміну за часом температури на боковій поверхні циліндра під час його охолодження. Ця функція змінюється не лише за часом, але також залежить від фізичних властивостей матеріалу циліндра та від температури середовища, в якому відбувається охолодження. Оскільки теплофізичні характеристики матеріалу зафіксовані лише у вигляді таблиць, то аналітичний вигляд функції $T_{\text {пов }}(t)$ потрібно побудувати.

Умови (4) випливають із симетричності температурного поля відносно осі циліндра.

Початкова і крайові умови повинні бути узгодженими між собою в точках $(r=0 ; t=0), \quad(r=R ; t=0)$. Це означає, що повинні виконуватися такі умови:

$$
\varphi(R)=T_{\text {пов }}(0),\left.\quad \frac{\partial \varphi(r)}{\partial r}\right|_{r=0}=0 .
$$

Шукаємо функцію $T(r, t)$ в області: $r \in[0, R], t \in\left[0, t_{\max }\right]$.

Перш ніж застосовувати чисельний метод до розв'язування задачі (1) - (5) потрібно тим функціям, які відомі лише у вигляді таблиць, надати аналітич- 
ного вигляду. Це дозволить обчислюватися значення цих відомих параметрів задачі у будь-якій точці області визначення шуканої функції $T(r, t)$.

Алгоритм методу розв'язування задачі передбачас виконання таких кроків.

1. Використовуючи відомі експериментальні дані для теплофізичних параметрів рівняння (1) і застосувавши метод середньоквадратичного наближення функцій, були побудовані аналітичні вирази для теплофізичних параметрів рівняння (1). Після виконання цього кроку алгоритму коефіцієнти $c(T), \rho(T), k(T)$ в диференціальному рівнянні (1) стають відомими в аналітичному вигляді. Графіки цих коефіцієнтів для випадку безрозмірного варіанта задачі показані на рис. 1, 2, 3. Маркери на рисунках вказують на табличні значення цих коефіцієнтів.

Аналогічно, спираючись на експериментальні дані роботи [2], була побудована функція $T_{\text {пов }}(t)$ крайової умови (3), яка описує процес охолодження бокової поверхні циліндра.

2. На другому кроці алгоритму диференціальне рівняння (1) та додаткові умови (2), (3), (4), (5) зведені до безрозмірного варіанта. Перехід виконано за рекомендаціями роботи [1].

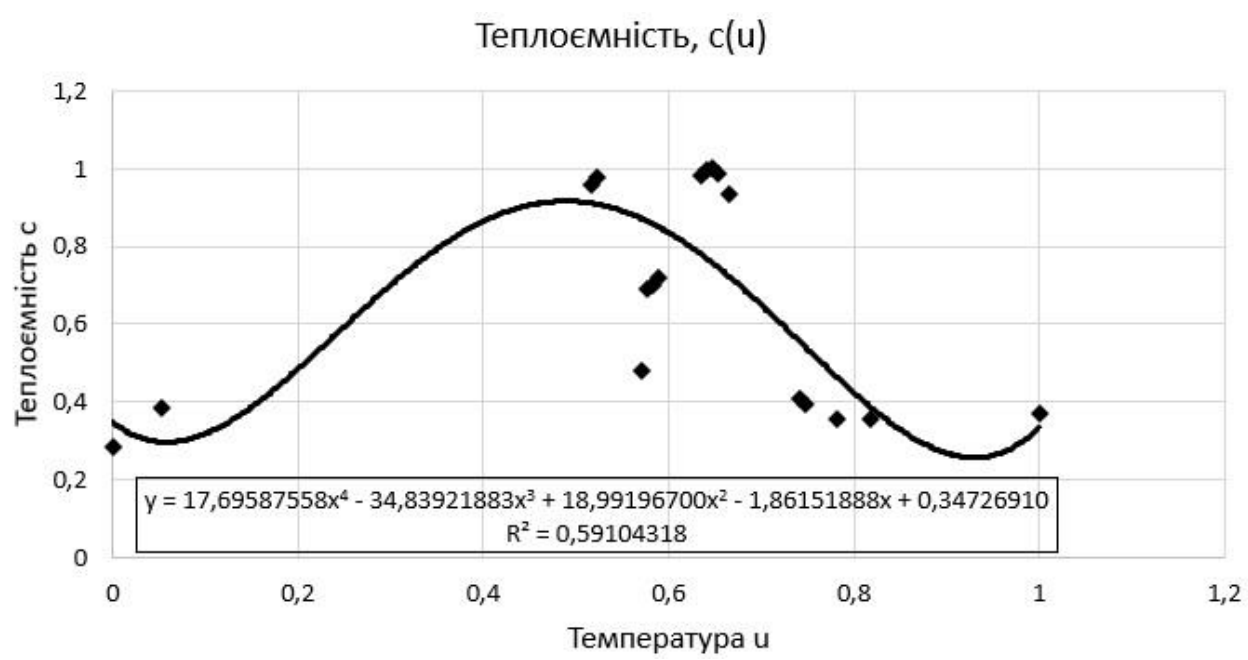

Рис. 1. Апроксимація коефіціснта питомої теплоємності

3. До безрозмірної задачі застосовано метод сіток з використанням явної різницевої схеми [1]. Був розроблений тестовий приклад, який дозволив встановити залежність між кроками по просторовій та часовій координатах, яка забезпечує стійкість явної різницевої схеми.

4. За рекомендаціями науковців ІЧМ був сформульований реальний приклад задачі (1) - (5). Приклад був переведений до безрозмірного варіанта, виконано розрахунок і результати переведені на розмірний (зручний для користувачів) варіант. За бажанням користувачів розроблена програма дозволяє подавати результати у вигляді таблиць, графіків, або виконати візуалізацію температурного поля. 


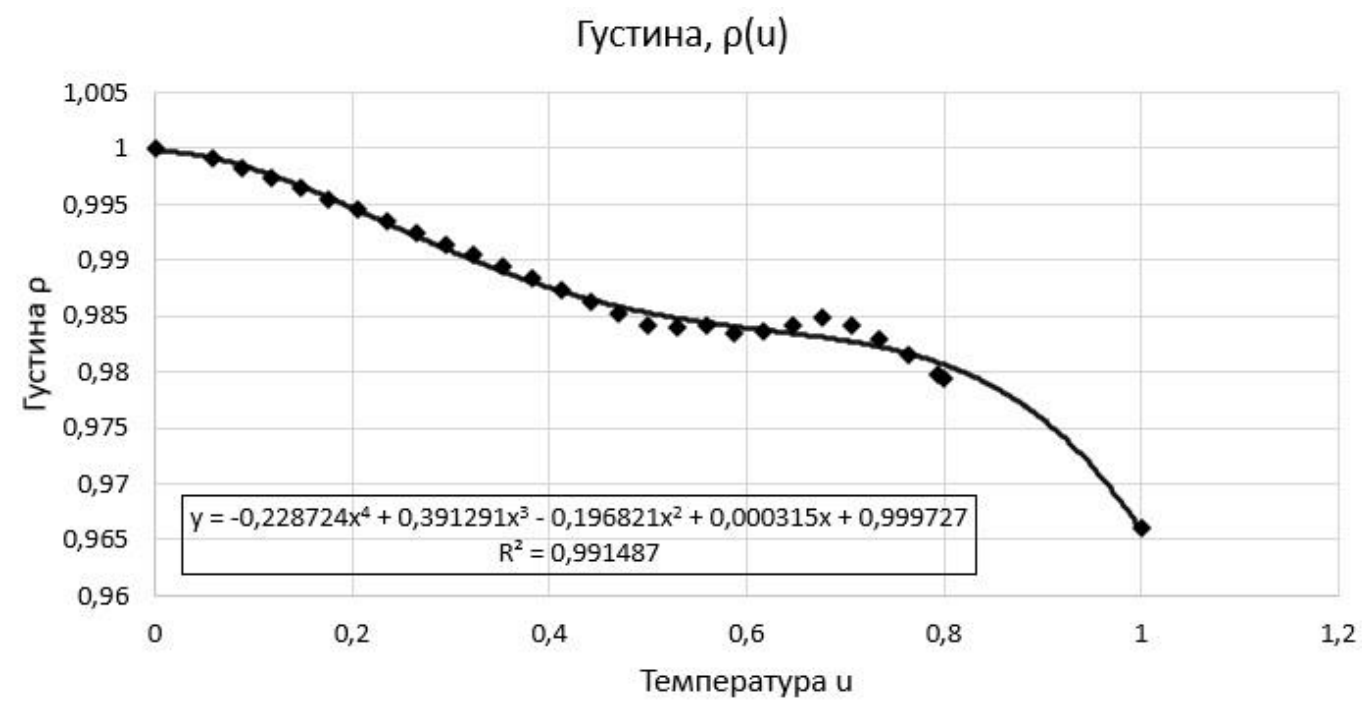

Рис. 2. Апроксимація коефіціснта густини матеріалу

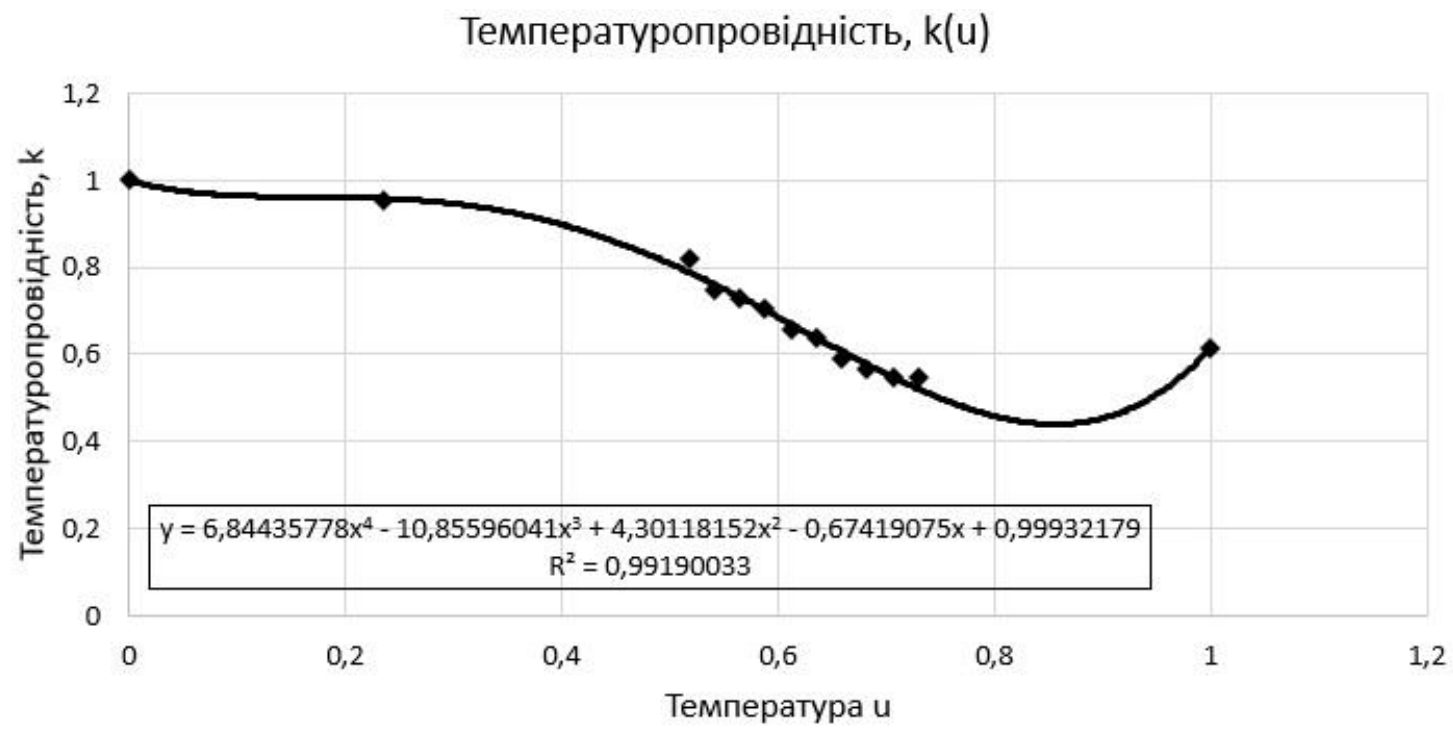

Рис. 3. Апроксимація коефіціснта температуропровідності

Опис розробленого програмного продукту. Була створена програма, яке демонструє розподіл температури всередині циліндра по ізотермах і зміну цього розподілу із плином часу.

На рис. 4 показано головний екран програми. У правій частині екрану можна задати параметри охолодження, а саме: радіус циліндра, який охолоджується, час, протягом якого буде проходити охолодження, та кількість розбиттів по просторовій координаті.

Після запуску охолодження (після натискання на кнопку «Почати охолодження») розраховується температура у табличному вигляді у безрозмірних змінних та відбувається перехід до розмірних змінних. 3'являється можливість побачити ці результати на вкладках «Розмірний результат» та «Безрозмірний результат» (рис. 6 та рис. 7 відповідно). Саме на результатах у розмірних змінних відбувається візуалізація процесу охолодження циліндра. 


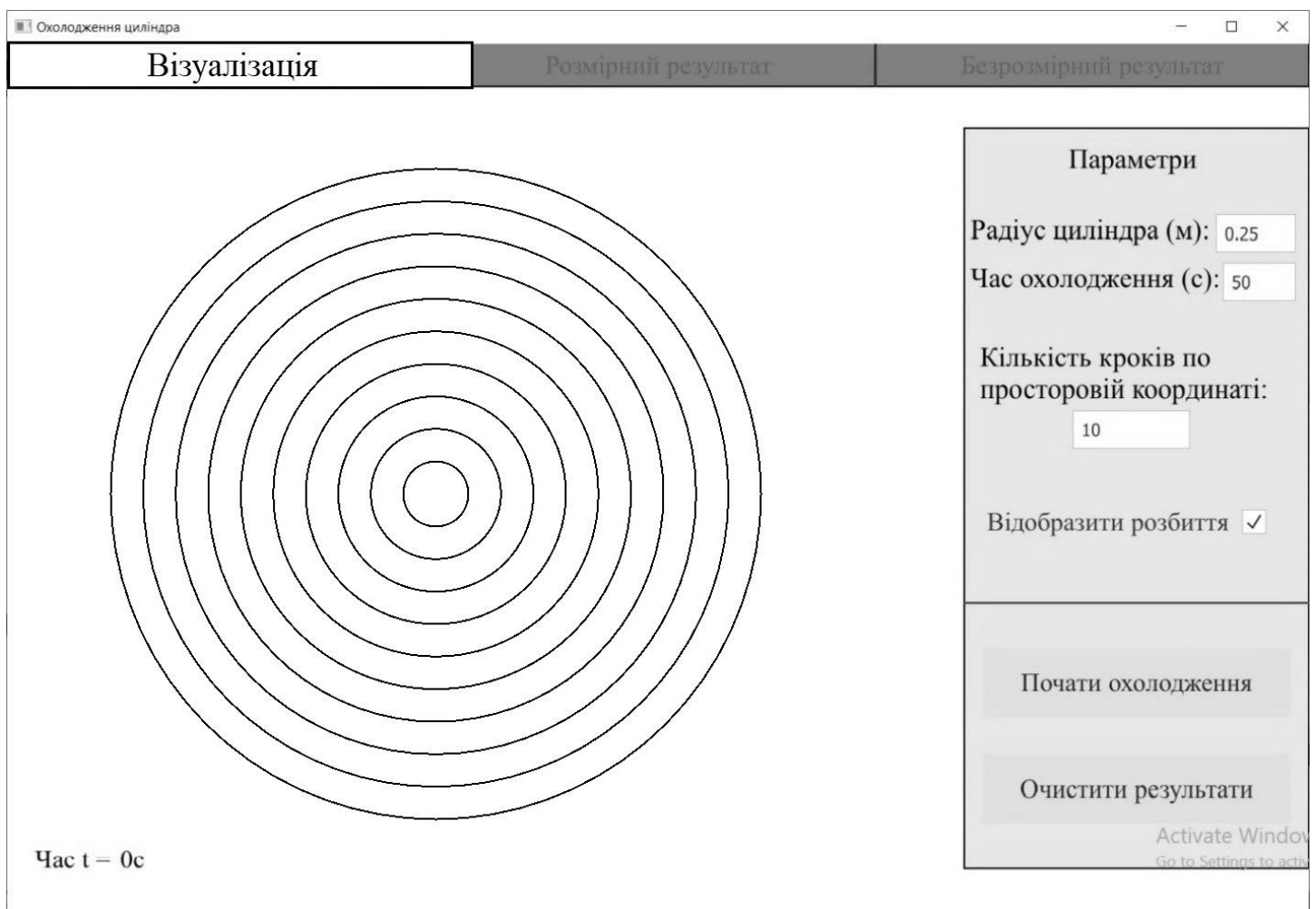

Рис. 4. Головний екран програми з візуалізацією

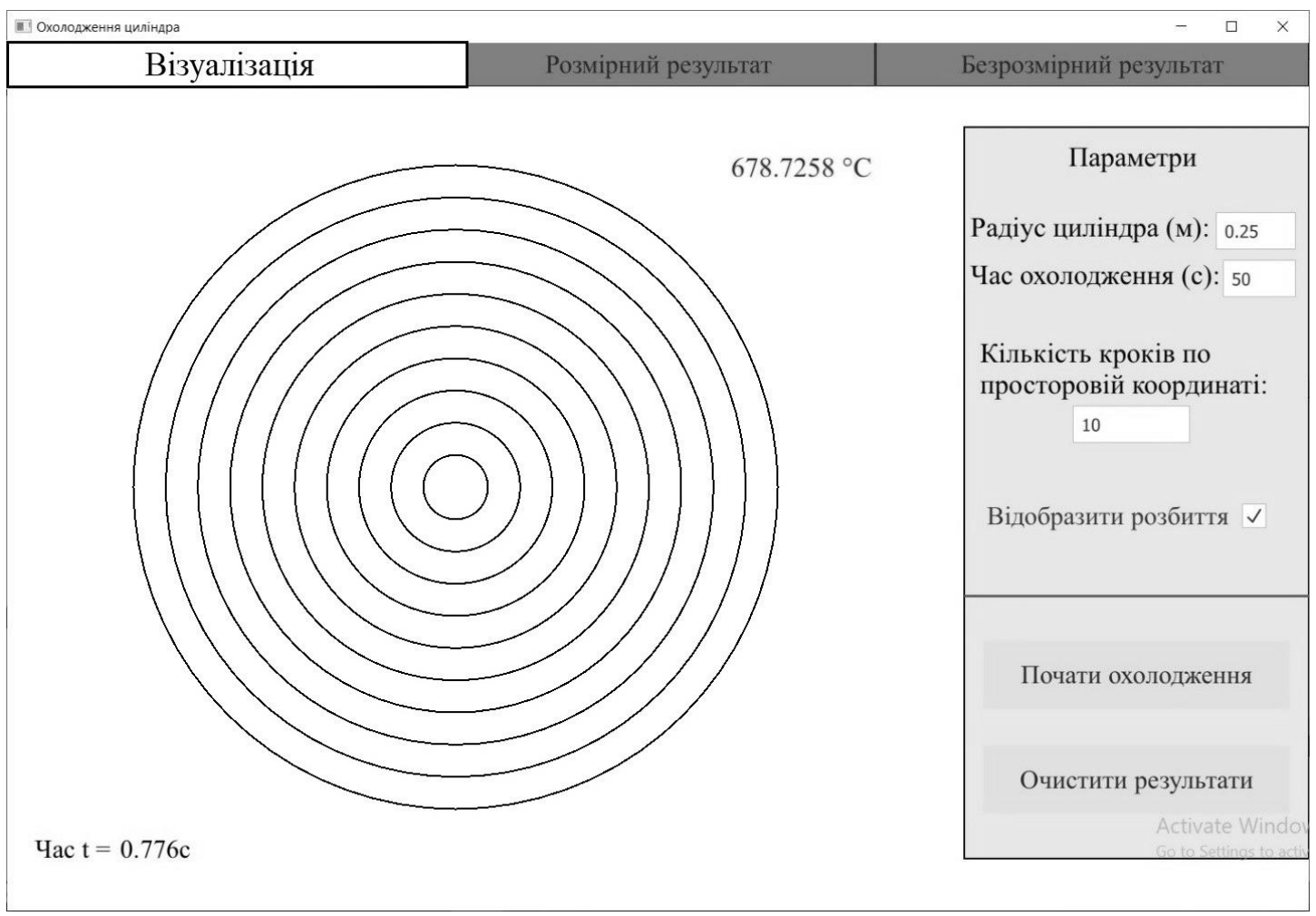

Рис. 5. Візуалізація процесу охолодження 


\begin{tabular}{|c|c|c|c|c|c|c|c|c|c|c|c|}
\hline & $\mathrm{Bi}$ & зація & & & & 3мірн & pezy. & aT & & \multicolumn{2}{|c|}{ Безрозмірний } \\
\hline Чac(c) / Рaaiyc(M) & 0.0 & 0.0025 & 0.005 & 0.0075 & 0.01 & 0.0125 & 0.015 & 0.0174 & 0.02 & 0.0225 & 0.0249 \\
\hline 0 & 850 & 850 & 850 & 850 & 850 & 850 & 850 & 850 & 850 & 850 & 850 \\
\hline 0.0369 & 850 & 850 & 850 & 850 & 850 & 850 & 850 & 850 & 850 & 850 & 771.3724 \\
\hline 0.0739 & 850 & 850 & 850 & 850 & 850 & 850 & 850 & 850 & 850 & 847.0185 & 680.087 \\
\hline 0.1108 & 850 & 850 & 850 & 850 & 850 & 850 & 850 & 850 & 849.8797 & 840.6939 & 631.9789 \\
\hline 0.1478 & 850 & 850 & 850 & 850 & 850 & 850 & 850 & 849.9951 & 849.5166 & 832.5594 & 598.1053 \\
\hline 0.1847 & 850 & 850 & 850 & 850 & 850 & 850 & 849.9998 & 849.9759 & 848.8612 & 823.1615 & 570.8027 \\
\hline 0.2217 & 850 & 850 & 850 & 850 & 850 & 849.9999 & 849.9988 & 849.9318 & 847.8892 & 812.8383 & 547.4064 \\
\hline 0.2586 & 850 & 850 & 850 & 850 & 849.9999 & 849.9999 & 849.9961 & 849.852 & 846.5889 & 801.9081 & 526.643 \\
\hline 0.2956 & 850 & 850 & 850 & 849.9999 & 849.9999 & 849.9997 & 849.9904 & 849.7261 & 844.9595 & 790.7006 & 507.793 \\
\hline 0.3325 & 850 & 850 & 849.9999 & 849.9999 & 849.9999 & 849.9994 & 849.9801 & 849.5447 & 843.0094 & 779.5316 & 490.4056 \\
\hline 0.3695 & 850 & 849.9999 & 849.9999 & 849.9999 & 849.9999 & 849.9986 & 849.9633 & 849.2992 & 840.7559 & 768.6559 & 474.177 \\
\hline 0.4064 & 850 & 849.9999 & 849.9999 & 849.9999 & 849.9999 & 849.9972 & 849.9378 & 848.9825 & 838.2236 & 758.2381 & 458.8919 \\
\hline 0.4434 & 850 & 849.9999 & 849.9999 & 849.9999 & 849.9998 & 849.9949 & 849.9016 & 848.5889 & 835.4407 & 748.3532 & 444.3912 \\
\hline 0.4804 & 850 & 849.9999 & 849.9999 & 849.9999 & 849.9996 & 849.9914 & 849.8523 & 848.1141 & 832.4373 & 739.0109 & 430.5536 \\
\hline 0.5173 & 850 & 849.9999 & 849.9999 & 849.9999 & 849.9993 & 849.9861 & 849.7876 & 847.5552 & 829.2434 & 730.1815 & 417.2846 \\
\hline 0.5543 & 850 & 849.9999 & 849.9999 & 849.9999 & 849.9987 & 849.9786 & 849.7054 & 846.9107 & 825.8874 & 721.8178 & 404.5083 \\
\hline 0.5912 & 850 & 849.9999 & 849.9999 & 849.9999 & 849.998 & 849.9683 & 849.6035 & 846.1799 & 822.3963 & 713.8676 & 392.1633 \\
\hline 0.6282 & 850 & 849.9999 & 849.9999 & 849.9998 & 849.9969 & 849.9548 & 849.48 & 845.3631 & 818.7951 & 706.2803 & 380.199 \\
\hline 0.6651 & 850 & 849.9999 & 849.9999 & 849.9997 & 849.9953 & 849.9372 & 849.3329 & 844.4615 & 815.1068 & 699.0101 & 368.5732 \\
\hline 0.7021 & 850 & 849.9999 & 849.9999 & 849.9995 & 849.9931 & 849.9151 & 849.1607 & 843.4768 & 811.3529 & 692.0166 & 357.25 \\
\hline 0.739 & 850 & 849.9999 & 849.9999 & 849.9993 & 849.9902 & 849.8878 & 848.9617 & 842.4114 & 807.5528 & 685.265 & 346.1994 \\
\hline 0.776 & 850 & 849.9999 & 849.9999 & 849.9989 & 849.9864 & 849.8544 & 848.7348 & 841.268 & 803.7241 & 678.7258 & 335.3952 \\
\hline 0.8129 & 850 & 849.9999 & 849.9998 & 849.9985 & 849.9816 & 849.8145 & 848.4786 & 840.0497 & 799.8824 & 672.3736 & 324.8153 \\
\hline 0.8499 & 850 & 849.9999 & 849.9998 & 849.9978 & 849.9755 & 849.7672 & 848.1924 & 838.7602 & 796.0416 & 666.1866 & 314.4404 \\
\hline 0.8869 & 850 & 849.9999 & 849.9997 & 849.997 & 849.968 & 849.7119 & 847.8753 & 837.4032 & 792.2133 & 660.1465 & 304.2539 \\
\hline 0.9238 & 850 & 849.9999 & 849.9996 & 849.9959 & 849.9588 & 849.648 & 847.5267 & 835.9825 & 788.4074 & 654.2375 & 294.2415 \\
\hline 0.9608 & 850 & 849.9999 & 849.9995 & 849.9946 & 849.9477 & 849.5747 & 847.1462 & 834.5023 & 784.6318 & 648.4459 & 284.3911 \\
\hline 0.9977 & 850 & 849.9998 & 849.9993 & 849.9929 & 849.9345 & 849.4916 & 846.7335 & 832.9668 & 780.893 & 642.76 & 274.6924 \\
\hline
\end{tabular}

Рис. 6. Результат роботи програми у розмірних змінних

\begin{tabular}{|c|c|c|c|c|c|c|c|c|c|c|c|}
\hline \multicolumn{5}{|c|}{ Візуалізація } & \multicolumn{5}{|c|}{ Розмірний результат } & \multicolumn{2}{|c|}{ Безрозмірний } \\
\hline 4ac/ Paдiyc & 0.0 & 0.1 & 0.2 & 0.3 & 0.4 & 0.5 & 0.6 & 0.7 & 0.7999 & 0.9 & 0.9999 \\
\hline 0 & 1 & 1 & 1 & 1 & 1 & 1 & 1 & 1 & 1 & 1 & 1 \\
\hline 0.0002 & 1 & 1 & 1 & 1 & 1 & 1 & 1 & 1 & 1 & 1 & 0.9074 \\
\hline 0.0004 & 1 & 1 & 1 & 1 & 1 & 1 & 1 & 1 & 1 & 0.9964 & 0.8001 \\
\hline 0.0006 & 1 & 1 & 1 & 1 & 1 & 1 & 1 & 1 & 0.9998 & 0.989 & 0.7435 \\
\hline 0.0008 & 1 & 1 & 1 & 1 & 1 & 1 & 1 & 0.9999 & 0.9994 & 0.9794 & 0.7036 \\
\hline 0.001 & 1 & 1 & 1 & 1 & 1 & 1 & 0.9999 & 0.9999 & 0.9986 & 0.9684 & 0.6715 \\
\hline 0.0012 & 1 & 1 & 1 & 1 & 1 & 0.9999 & 0.9999 & 0.9999 & 0.9975 & 0.9562 & 0.644 \\
\hline 0.0014 & 1 & 1 & 1 & 1 & 0.9999 & 0.9999 & 0.9999 & 0.9998 & 0.9959 & 0.9434 & 0.6195 \\
\hline 0.0016 & 1 & 1 & 1 & 0.9999 & 0.9999 & 0.9999 & 0.9999 & 0.9996 & 0.994 & 0.9302 & 0.5974 \\
\hline 0.0018 & 1 & 1 & 0.9999 & 0.9999 & 0.9999 & 0.9999 & 0.9999 & 0.9994 & 0.9917 & 0.917 & 0.5769 \\
\hline 0.002 & 1 & 0.9999 & 0.9999 & 0.9999 & 0.9999 & 0.9999 & 0.9999 & 0.9991 & 0.9891 & 0.9043 & 0.5578 \\
\hline 0.0022 & 1 & 0.9999 & 0.9999 & 0.9999 & 0.9999 & 0.9999 & 0.9999 & 0.9988 & 0.9861 & 0.892 & 0.5398 \\
\hline 0.0024 & 1 & 0.9999 & 0.9999 & 0.9999 & 0.9999 & 0.9999 & 0.9998 & 0.9983 & 0.9828 & 0.8804 & 0.5228 \\
\hline 0.0026 & 1 & 0.9999 & 0.9999 & 0.9999 & 0.9999 & 0.9999 & 0.9998 & 0.9977 & 0.9793 & 0.8694 & 0.5065 \\
\hline 0.0028 & 1 & 0.9999 & 0.9999 & 0.9999 & 0.9999 & 0.9999 & 0.9997 & 0.9971 & 0.9755 & 0.859 & 0.4909 \\
\hline 0.003 & 1 & 0.9999 & 0.9999 & 0.9999 & 0.9999 & 0.9999 & 0.9996 & 0.9963 & 0.9716 & 0.8491 & 0.4758 \\
\hline 0.0032 & 1 & 0.9999 & 0.9999 & 0.9999 & 0.9999 & 0.9999 & 0.9995 & 0.9955 & 0.9675 & 0.8398 & 0.4613 \\
\hline 0.0034 & 1 & 0.9999 & 0.9999 & 0.9999 & 0.9999 & 0.9999 & 0.9993 & 0.9945 & 0.9632 & 0.8309 & 0.4472 \\
\hline 0.0036 & 1 & 0.9999 & 0.9999 & 0.9999 & 0.9999 & 0.9999 & 0.9992 & 0.9934 & 0.9589 & 0.8223 & 0.4336 \\
\hline 0.0038 & 1 & 0.9999 & 0.9999 & 0.9999 & 0.9999 & 0.9999 & 0.999 & 0.9923 & 0.9545 & 0.8141 & 0.4202 \\
\hline 0.004 & 1 & 0.9999 & 0.9999 & 0.9999 & 0.9999 & 0.9998 & 0.9987 & 0.991 & 0.95 & 0.8061 & 0.4072 \\
\hline 0.0042 & 1 & 0.9999 & 0.9999 & 0.9999 & 0.9999 & 0.9998 & 0.9985 & 0.9897 & 0.9455 & 0.7985 & 0.3945 \\
\hline 0.0044 & 1 & 0.9999 & 0.9999 & 0.9999 & 0.9999 & 0.9997 & 0.9982 & 0.9882 & 0.941 & 0.791 & 0.3821 \\
\hline 0.0046 & 1 & 0.9999 & 0.9999 & 0.9999 & 0.9999 & 0.9997 & 0.9978 & 0.9867 & 0.9365 & 0.7837 & 0.3699 \\
\hline 0.0047 & 1 & 0.9999 & 0.9999 & 0.9999 & 0.9999 & 0.9996 & 0.9975 & 0.9851 & 0.932 & 0.7766 & 0.3579 \\
\hline 0.0049 & 1 & 0.9999 & 0.9999 & 0.9999 & 0.9999 & 0.9995 & 0.997 & 0.9835 & 0.9275 & 0.7696 & 0.3461 \\
\hline 0.0051 & 1 & 0.9999 & 0.9999 & 0.9999 & 0.9999 & 0.9994 & 0.9966 & 0.9817 & 0.923 & 0.7628 & 0.3345 \\
\hline 0.0053 & 1 & 0.9999 & 0.9999 & 0.9999 & 0.9999 & 0.9994 & 0.9961 & 0.9799 & 0.9186 & 0.7561 & 0.3231 \\
\hline
\end{tabular}

Рис. 7. Результат роботи програми у безрозмірних змінних

Ізотерми, показані на рисунку 5, змінюють свій колір відповідно до температури у даний момент часу, час можна побачити у лівій нижній частині вікна програми. Колір ізотерм змінюється від червоного (максимальна початкова температура) до синього кольору (температура зовнішнього середовища). При наведені курсором миші на ізотерм, у правій верхній частині вікна про- 
грами можна побачити температуру на даний момент часу у даній області циліндра.

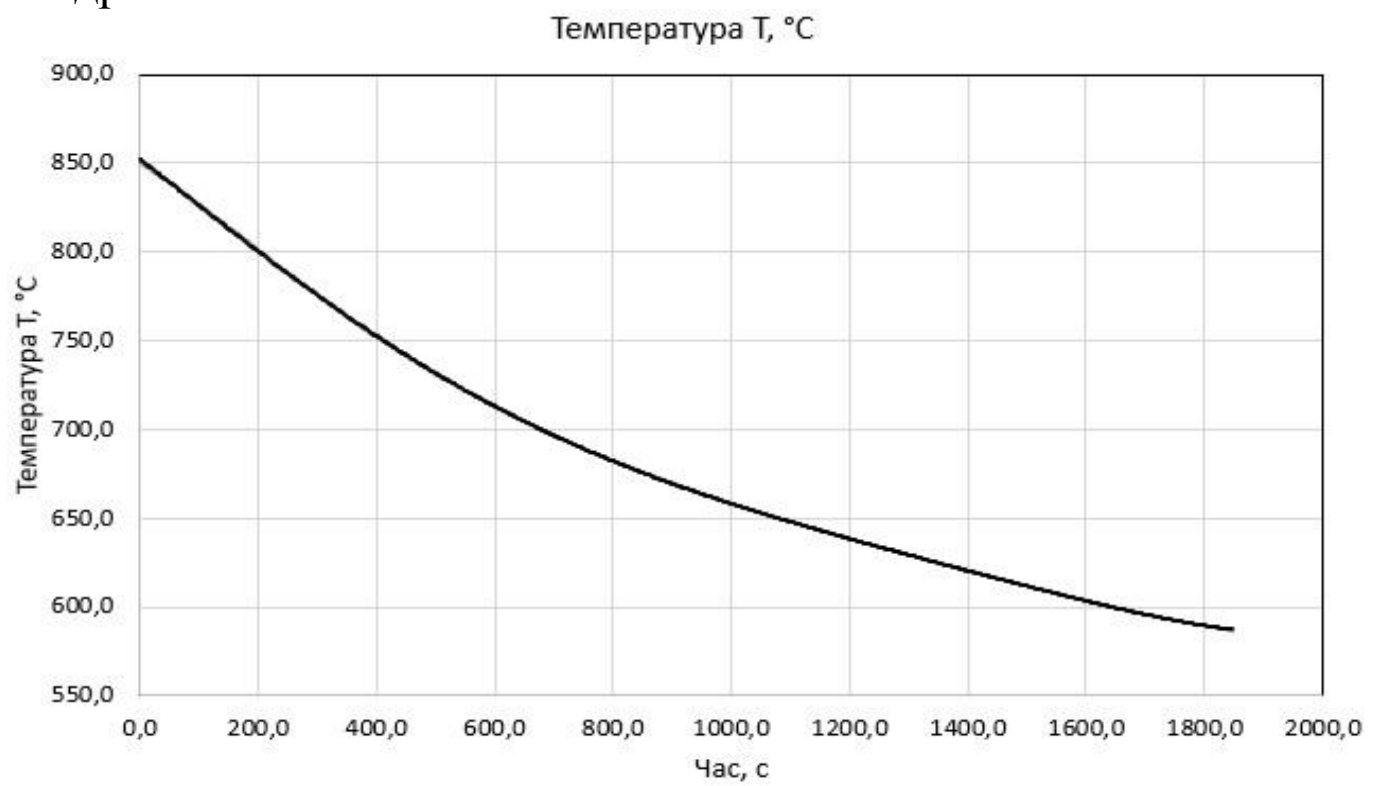

Рис. 8. Графік залежності температури бокової поверхні циліндра від часу

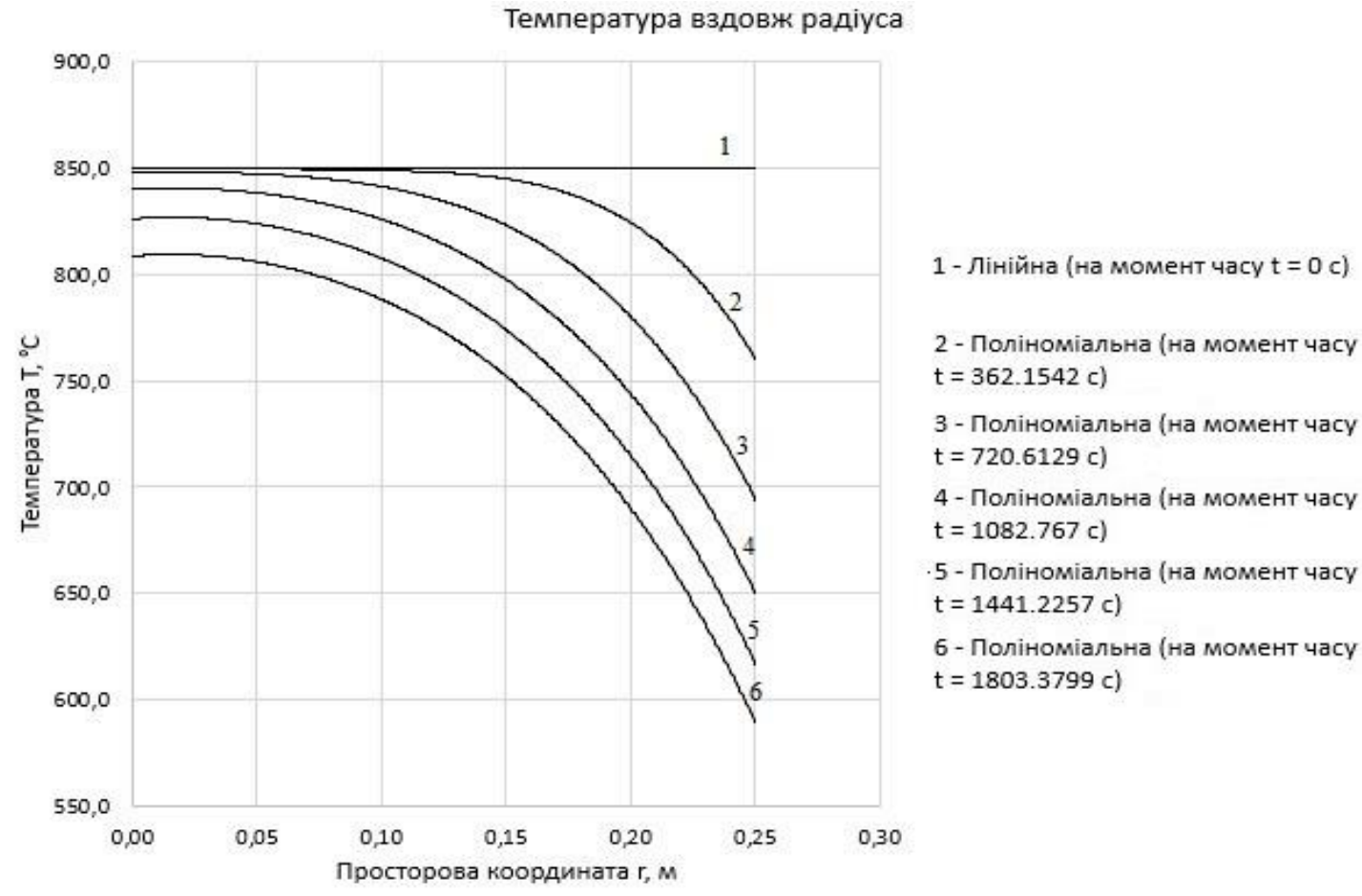

Рис. 9. Графік залежності температури вздовж радіуса циліндра від часу

Для спрощення аналізу результатів програма надає можливість будувати графіки залежності температури бокової поверхні циліндра від часу (рис. 8), та графіки залежності температури вздовж радіуса циліндра (рис. 9).

Висновки. Розроблено програмну реалізацію алгоритму розв'язування математичної моделі задачі теплопровідності для розігрітого циліндра під час його охолодження. Програма має зручний для користувача сервіс, який надає можливість проаналізувати процес охолодження циліндра. 
Результати роботи можуть бути використані при розробці режимів термічної обробки металопрокату з формами, наближеними до циліндра великої довжини, із сталей з різними теплофізичними властивостями.

Результати роботи програми обговорювалися на конференціях $[3,4,5]$.

\section{Бібліографічні посилання}

1. Самарский, А. А. Вычислительная теплопередача [Текст] / А. А. Самарский, П. Н. Вабищевич. - М.: Едиториал УРСС, 2003. - 784 с.

2. Охлаждающие среды // Информационный некоммерческий pecypc metal-archive.ru. Дата оновлення: 20.01.2015. URL: http:// metal-archive.ru/obrabotka-cvetnyh-metallov / 602ohlazhdayuschie-sredy.html\# (дата звернення: 05.11.2019).

3. Попов, I. В. Розробка програмного продукту для розв'язування одновимірного квазілінійного рівняння теплопровідності [Текст] / I .В. Попов, Л. Т. Бойко // Всеукраїнська науково-технічна конференція «Наука і металургія» присвячена 80-річчю Інституту чорної металургії ім. 3.І. Некрасова НАНУ / Тези доповідей. 9-10 жовтня, Дніпро, 2019. 50 c. C. $28-29$.

4. Popov, I.V. Software implementation of the algorithm for solving the one-dimensional quasilinear heat conduction equation. [Текст] / I.V. Popov, L.T. Вoyko // Тези доповіді. XVII міжнародна науково-практична конференція «Математичне та програмне забезпечення інтелектуальних систем» (МПЗІС-2019) /. Дніпро, 20-22 листопада 2019 р.- 308 с. C. 211-212.

5. Бабаченко, О.І. Реальний варіант одновимірної задачі теплопровідності для суцільного необмеженого сталевого циліндра [Текст] / О.І. Бабаченко, Л.Т. Бойко, Г.А. Кононенко // Матеріали міжнародної науково-технічної конференції «Інформаційні технології в металургії та машинобудуванні» імені професора Михальова O.I. (ITMМ'2020), 17-19 березня 2020 р. Дніпро / Д.: НМетАУ, 2020. - 501 с. С. 73 - 76.

Надійшла до редколегї 10.09. 2020. 